\title{
Pollen viability and stigma receptivity in Swainsona formosa (G.Don) J.Thompson (Fabaceae), an ornamental legume native to Australia
}

\author{
Zulkarnain Zulkarnain $^{1 *}$, Eliyanti Eliyanti ${ }^{1}$, Elly Indra Swari ${ }^{1}$
}

\begin{abstract}
Pollen viability and stigma receptivity are prerequisites for successful cross-pollination and seed set in Swainsona formosa. In this study, the pollen viabilities and stigma receptivities was assayed by in vitro pollen germination and simple hand-pollination method on glasshouse-grown plants, respectively. The viability of pollen grains was tested under three different storage conditions: 1) pollen grains were left on the plant in the glasshouse under natural conditions, 2) pollen grains were harvested and kept at a low temperature $\left(4^{\circ} \mathrm{C}\right)$ in total darkness, and 3$)$ pollen grains were kept in a dry freezer $\left(-10^{\circ} \mathrm{C}\right)$ and in total darkness. Meanwhile, stigma receptivity was determined by hand-pollination using fresh pollen grains on flower of glasshouse-grown plants at one day before anther dehiscence up to 8 days after anther dehiscence. The results showed that pollen grains could be stored at $4{ }^{\circ} \mathrm{C}$ for up to 28 days without significantly losing their viability. Pollen longevity could be extended beyond two months when stored at -10 ${ }^{\circ} \mathrm{C}$ and under dry conditions. These findings provided a simple and economically sound method for storage of $S$. formosa pollen. In addition, stigma receptivity was found to be receptive from one day before anther dehiscence and reached its peak within four days after anther dehiscence. These results provide a valuable background to the conventional breeding of this species to create hybrids through cross-pollination.
\end{abstract}

Keywords: Clianthus formosus, dessert pea, legume, plant breeding, native Australian flora.

\section{Introduction}

Cross-pollination technique in hybridisation has been practiced for many years in conventional plant breeding programs. The purpose is to transfer pollen from male reproductive organ of one individual to female reproductive organ of another individual Mangena and Mokwala (2018). This method requires either natural pollination by the assistance of birds, insects and wind, or artificially by hand-pollination. Artificial pollination is preferable in most breeding programs since it offers a an alternative to increase the seed set and guarantee high productivity (Dongarwar and Thakur, 2014; Gupta et al., 2017). Handpollination also prevents crossing between unwanted individuals to ensure that plants produce seed that is trueto-type.

The success of either artificial or natural pollination depends greatly upon the readiness of both male and female reproductive organs to undergo fertilisation and subsequent zygote development. This is indicated by the viability of the pollen grains and the receptivity of the stigma. It is often found that in certain plants hybridisation under natural conditions is not possible because maturation of both male and female reproductive organs does not take place simultaneously due to a wide variation in flowering response, e.g. in Pistacia vera (Vithanage, 1984) and Dendrathema grandiflora (Ikeda and Numata, 1996). In addition, the presence of stigmatic cuticle should be considered in the processes of pollen-pistil interaction (Edlund et al., 2004). Pollen will not germinate until the cuticle is ruptured, even though the plant is fully selfcompatible (Shivanna and Owens, 1989). This because the stigmatic cuticle represent a physical barrier avoiding contact between pollen and stigma (Costa et al., 2014). In Swainsona formosa, the presence of stigmatic cuticle has become an obstacle for the success of fertilization following pollination (Jusaitis, 1994).

For a successful hybridization program, a reliable method of pollen storage is required. Under controlled temperature and storage humidity this method has been successfully applied to a wide range of angiosperms such as almond (Martinez-gomez et al., 2000; 2002), Aechmea fasciata, A. chantinii, Vriesea splendens, Guzmania lingulata and Tillanproadsia cyanea (Parton et al., 2002), Melaleuca alternifolia (Baskorowati, 2009), Cocos nucifera (Machado et al., 2014), Imperata cylindrica (Rather et al., 2017) and Rosa hybrida (Giovannini et al., 2017). The preservation of $S$. formosa pollen was

\footnotetext{
${ }^{1}$ University of Jambi, Faculty of Agriculture, Agroecotechnology Department, Indonesia *Corresponding author: dr.zulkarnain@yahoo.com Received January 9, 2019| Accepted May 22, 2019

Licensed by CC BY 4.0

http://dx.doi.org/10.14295/oh.v25i2.2011
} 
first reported by Hughes et al. (1991). It was found that Clianthus formosus (syn. S. formosa) pollen grains can be stored for up to 11 days in dry conditions at $-180{ }^{\circ} \mathrm{C}$ without losing their viability. However, pollen storage at such a low temperature requires a specific facility such as a liquid nitrogen refrigerator. The procedure is also more complex as preserved pollen needs to be thawed before being used for pollination. In fact, not many laboratories or small-scale commercial nurseries have such a facility. Thus, this experiment sought a simple and economically sound technique for preserving $S$. formosa pollen grains for breeding purposes.

Stigma receptivity is another aspect that plays an important role in successful hybridizations. For fertilization to occur, not only should pollen grains be in a viable state, but also the stigma should be in a receptive condition. Arathi et al. (2002) suggested that stigma receptivity is an important determinant of reproductive success in plants. Unfortunately, the stigma receptivity of $S$. formosa is not well documented.

This research was aimed at studying pollen viability and longevity following cold storage, and stigma receptivity as an initial step in the conventional breeding of $S$. formosa. Understanding these aspects is important to ensure that pollen and stigma are ready to undergo fertilization when required.

\section{Materials and Methods}

\section{Pollen viability assessment}

The objective of this experiment was to study the viability of $S$. formosa pollen grains under different storage conditions.

This study consisted of three trials: 1) pollen grains were left on the plant (within the keel) in the glasshouse under natural conditions, 2) pollen grains were harvested and kept at a low temperature $\left(4^{\circ} \mathrm{C}\right)$ in total darkness, and 3$)$ pollen grains were kept in a dry freezer $\left(-10^{\circ} \mathrm{C}\right)$ and in total darkness. In the first trial, pollen grains were taken from five umbels of 10 glasshouse-grown plants (designated as replicates) on the day of anther dehiscence, through to 10 days after anther dehiscence, at daily intervals. Each umbel consisted of 5-7 flowers. Pollen grains from the flowers of the same umbel were mixed in a vial before viability assessment. In the second trial, pollen grains were harvested from 5 umbels from 10 different glasshouse-grown plants on the day of anther dehiscence, collected, mixed in a vial, and kept in a refrigerator at $4{ }^{\circ} \mathrm{C}$. The method of the third trial was identical to the second trial, except that the pollen grains were kept in a freezer at $-10{ }^{\circ} \mathrm{C}$ instead of a refrigerator. Pollen collection in all trials was carried out between 9.00 and $10.00 \mathrm{am}$.

The viability assessment was carried out by germinating pollen on a modified BK medium (Brewbaker and Kwack, $1963)$ containing $720 \mathrm{ppm} \mathrm{Ca}\left(\mathrm{NO}_{3}\right)_{2} \times 4 \mathrm{H}_{2} \mathrm{O}, 200 \mathrm{ppm}$ $\mathrm{MgSO}_{4} \times 7 \mathrm{H}_{2} \mathrm{O}, 200$ ppm $\mathrm{KNO}_{3}, 20$ ppm $\mathrm{H}_{3} \mathrm{BO}_{3}$ and $10 \%$ sucrose. Pollen was spread evenly on the surface of one drop of this medium on a clean microscope slide. The slides were placed in closed Petri dishes on a layer of moistened filter paper to allow the pollen to germinate. The dishes were kept at room temperature under a light intensity of $50 \mu \mathrm{mol} \mathrm{m} \mathrm{m}^{-2} \mathrm{~s}^{-1}$. No cover glass was used, as free access to air was necessary for the pollen to germinate. Pollen cultures were left for 120 minutes to obtain the maximum germination before assessment. The slides were set up at 10 minutes intervals and the first slide was examined after 120 minutes. Examination of the slide took approximately 10 minutes by which the second slide was ready for examination. This pattern was continued until all slides were examined and this ensured a uniformity of 120 minutes culture for each slide.

The examination of pollen viability was carried out according to the protocol of Prakash (2000). Pollen grains were dusted on a drop of aceto-orcein on a microscope slide, covered with a cover slip and examined under a light microscope. Dark red stained pollen grains were recorded as viable, whereas pale red stained and colorless grains were classified as unviable.

Except for the pollen left within the keel, the water content of the pollen was determined prior to storage at low temperature. Samples of fresh pollen from different plants were collected in a weighing tray and the fresh weight was measured using an analytical balance. Pollen was then left to dry in a desiccator and the dry weight was determined after 24 hours. Pollen water content was then calculated, and it was $6.6 \%-7.3 \%$ at the time of harvesting,

Each trial was arranged in a Completely Randomized Design, with 10 replicates (plants). There were 10 fields of view (observations) on each replicate. The percentage of pollen germination was determined by counting the number of pollen grains forming tubes, divided by the total number of pollen grains that were found in one field of view under the light microscope. Only pollen grains having a tube length of at least half of the pollen diameter were counted.

\section{Stigma receptivity assessment}

This work sought to ascertain the time at which the stigma of $S$. formosa was most receptive, so that the optimal time for hand-pollination in the glasshouse could be determined.

Flowers were emasculated one day prior to anther dehiscence, or stage four according to Jusaitis (1994). This was the earliest that the floral buds could be manipulated without causing damage. The emasculated flowers were left unpollinated up to 8 days after anther dehiscence, depending on the treatment. In addition, pollinations were also performed on flowers with just-dehiscing anthers and on flowers with non-dehiscing anthers (on the day of emasculation). The flowers of all treatments were pollinated in one day and this was the same day as the pollination of flowers with just-dehiscing anthers.

The stigma was rubbed several times with a fingertip to remove the stigmatic cuticle and to expose the stigmatic surface. The stigmatic surface was pollinated with fresh pollen grains at the time indicated by the following treatments: 
$\mathrm{A}=$ flower emasculated 8 days after anther dehiscence $\mathrm{B}=$ flower emasculated 7 days after anther dehiscence $\mathrm{C}=$ flower emasculated 6 days after anther dehiscence $\mathrm{D}=$ flower emasculated 5 days after anther dehiscence $\mathrm{E}=$ flower emasculated 4 days after anther dehiscence $\mathrm{F}=$ flower emasculated 3 days after anther dehiscence $\mathrm{G}=$ flower emasculated 2 days after anther dehiscence $\mathrm{H}=$ flower emasculated 1 days after anther dehiscence $\mathrm{I}=$ flower emasculated on the day of anther dehiscence $\mathrm{J}=$ flower emasculated one day before anther dehiscence.

In order to minimise the experimental error due to environmental variation, all the pollen grains were collected from just-dehiscing anthers of approximately 100 flowers, mixed in a vial and tested for their viability prior to pollination. The pollen viability test indicated that the germination rate on BK medium was between $60 \%$ to $65 \%$.
Three umbels (one from each stem) consisting of 5-7 flowers were selected as floral samples for emasculation. There were 4 replicates (plants) for each treatment. The number of pods formed following compatible pollination was used as the parameter of stigma receptivity in this trial.

\section{Results}

Swainsona formosa has a large, flag-like flower, up to $10 \mathrm{~cm}$ long, colored red with a dark red or black boss. The flower consists of five sepals and a five-part corolla that are typical to legumes. The petals incorporate a shiny dark red or black boss and a lower keel that houses the sexual organs. The inflorescences consist of clusters (umbels) of up to six flowers in a whorl at the end of short upright. The peduncle may be up to $20 \mathrm{~cm}$ long making it potential as a cut flower plant (Figure 1) (Zulkarnain, 2018).

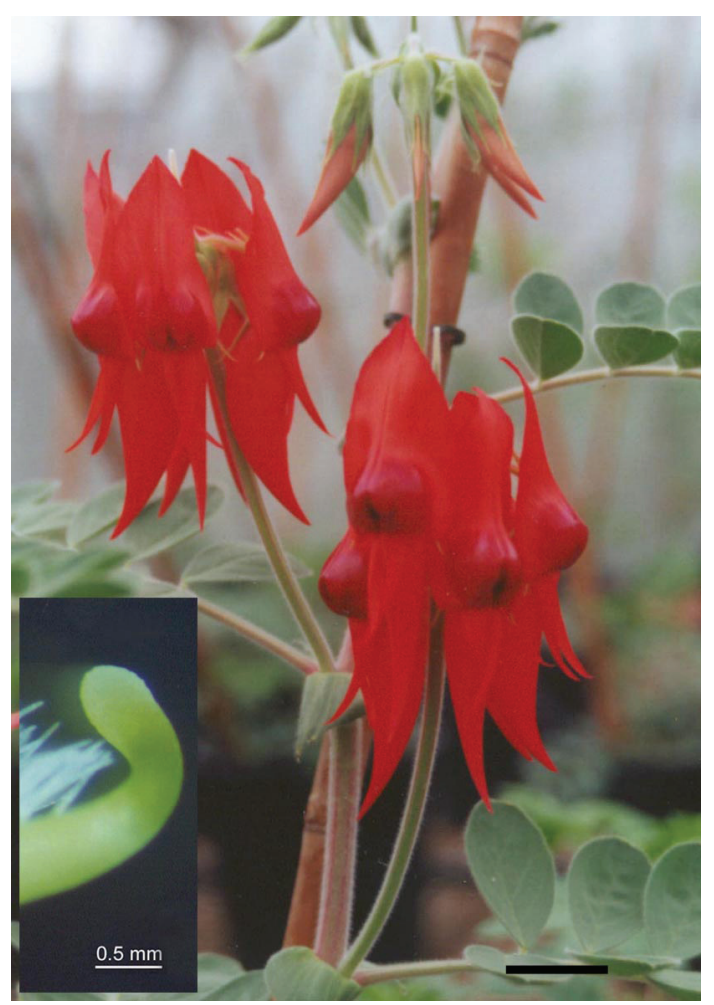

Figure 1. Flowers of $S$. formosa $($ bar $=2 \mathrm{~cm})$. Insert: the stigma at maturity.

\section{Pollen viability assessment}

The viability of pollen grains was initially high at the time of collection (more than $50 \%$ pollen germinated in $\mathrm{BK}$ medium). If pollen grains were left within the keel of the flowers on the plants in the glasshouse under natural environmental conditions, the viability was still reasonably high ( $>50 \%$ pollen germination) for up to 4 days after anther dehiscence. The viability dropped dramatically on the $5^{\text {th }}$ day, indicated by the percentage of pollen germination (less than $40 \%$ ). A further decrease in pollen viability (less than $20 \%$ pollen germinated) was found on the $10^{\text {th }}$ day after anther dehiscence (Figure 2).

However, if pollen grains were isolated from the plants and kept at a low temperature $\left(4{ }^{\circ} \mathrm{C}\right)$ in total darkness, the viability remained high ( $>50 \%$ pollen germination) for up to 21 days of storage. Prolonged storage for more than 21 days was found to reduce pollen viability (Figure 3). 


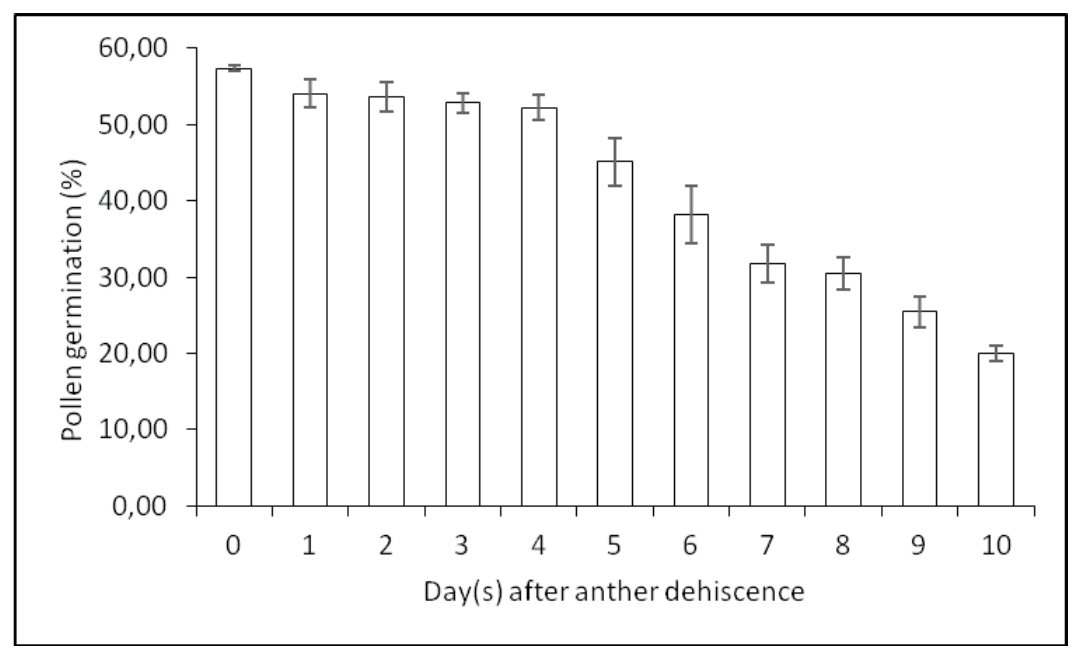

Figure 2. Germination of $S$. formosa pollen grains from day 0 through to day 10 (after anther dehiscence), when pollen were left within the keel of flowers on plants in glasshouse.

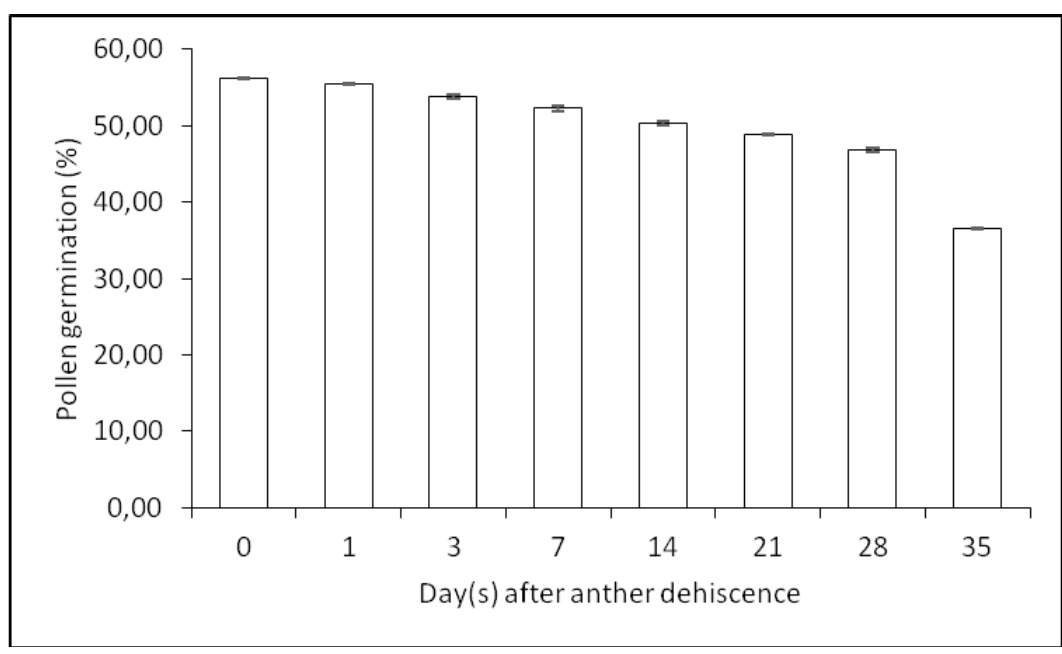

Figure 3. Germination of $S$. formosa pollen grains from day 0 through to day 35 (after anther dehiscence), when kept at $4{ }^{\circ} \mathrm{C}$ in total darkness.

When pollen grains were isolated from the plants and kept at $-10{ }^{\circ} \mathrm{C}$, a different pattern of pollen germination was found. Initially, the rate of germination (58.96\%) was similar to that in the trial of low temperature $\left(4{ }^{\circ} \mathrm{C}\right)$ but during the first 3 days of freezing, pollen germination increased up to $73.28 \%$. The rate of pollen germination remained high up to 56 days of storage at $-10{ }^{\circ} \mathrm{C}$ (Figure 4). 


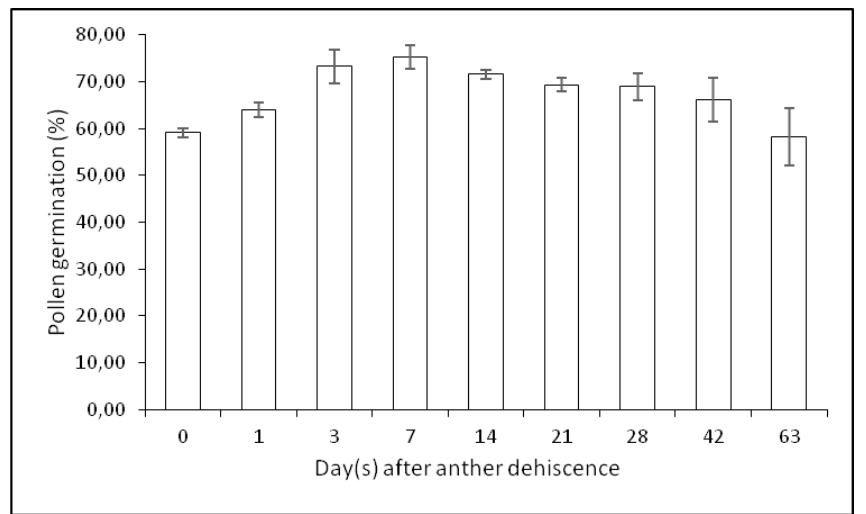

Figure 4. Germination of $S$. formosa pollen grains from day 0 through to day 63 (after anther dehiscence), when kept at $-10^{\circ} \mathrm{C}$ in total darkness.

The examination of pollen viability using aceto-orcein staining showed that the viable pollen grains were round in shape and were dark brownish-red stained. Meanwhile, non viable pollen grains had an irregular shape and were pale brownish-red stained (Figure 5).

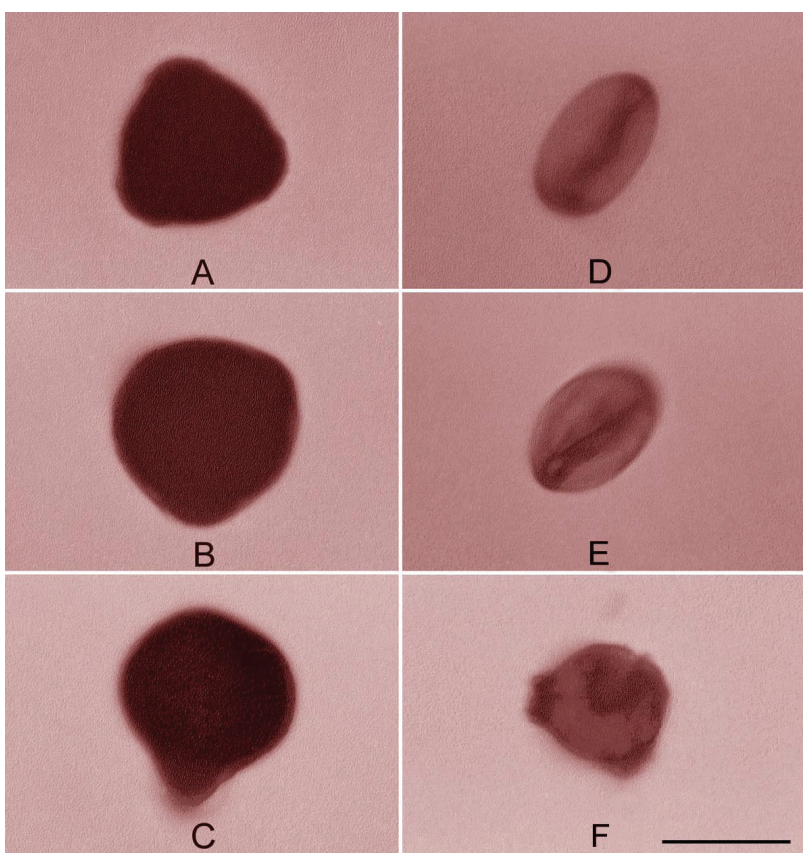

Figure 5. The difference of viable and unviable pollen grains of $S$. formosa as indicated by aceto-orcein staining. A-C, viable pollen grain; D-F, unviable pollen grains. Bar $=10 \mu \mathrm{m}$.

This study showed that the wall of $S$. formosa pollen consisted of two layers, i.e. the outer and the inner layer (Figure 6A). In certain areas the wall of $S$. formosa pollen was found to be thinner. These regions are known as germinal pores through which the pollen tube may emerge on germination (Figure 6B). Present investigation revealed that $S$. formosa pollen is of tricolporate type, indicated by the presence of 3 pores on each pollen grain. Tricolporate pollen is common in Papilionoideae (Avci et al., 2013; Banks and Lewis, 2018). 

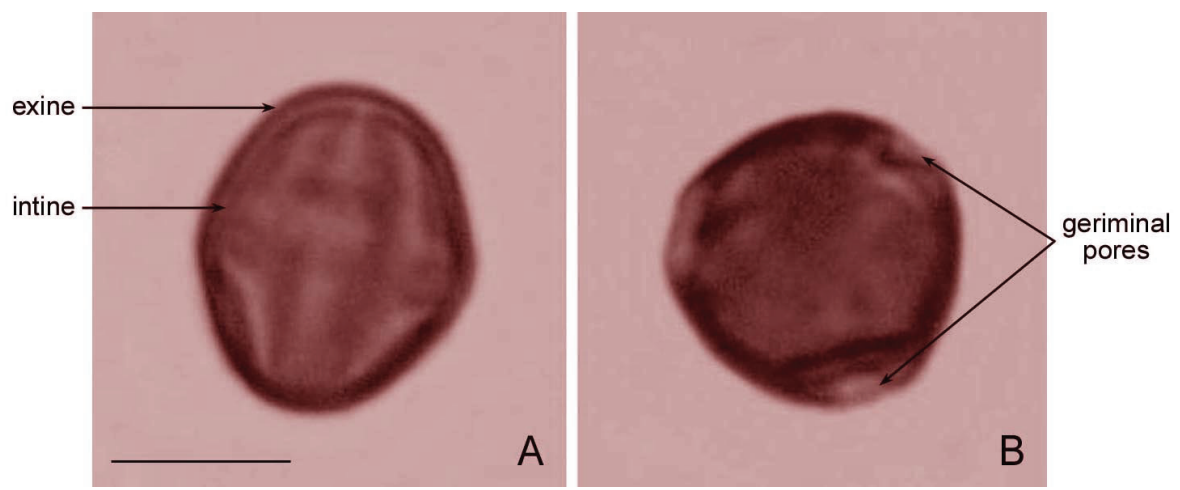

Figure 6. Pollen grains of $S$. formosa. A, showing exine and intine layers of pollen wall; $\mathrm{B}$, showing 3 germinal pores. Bar $=10 \mu \mathrm{m}$.

\section{Stigma receptivity assessment}

The results indicated that one day before anther dehiscence the stigma has already become receptive (Figure 7). The stigma receptivity reached its peak on the $2^{\text {nd }}$ and the $3^{\text {rd }}$ day after anther dehiscence, indicated by $100 \%$ pod formation, and gradually started to decrease from the $4^{\text {th }}$ day. On the $8^{\text {th }}$ day after anther dehiscence, the petals started to degenerate and the stigma receptivity decreased significantly. On the $9^{\text {th }}$ day after anther dehiscence, flowers were too flaccid to be pollinated. This was the time at which the abscission layer at the pedicel-peduncle junction had developed to the point that abscission was inevitable. At this stage the stigma had completely lost its receptivity.

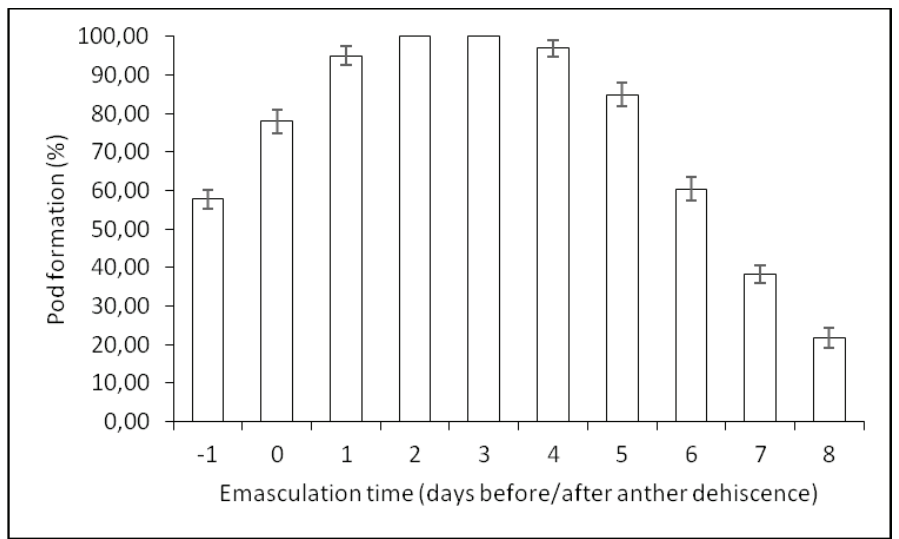

Figure 7. Stigma receptivity in relation to the time of emasculation in glasshouse-grown $S$. formosa flowers (day -1 means pollination was carried out one day before anther dehiscence).

\section{Discussion}

\section{Pollen viability}

It has been known that $S$. formosa is able to flower all year round (Tapingkae et al., 2009), although for some reason there may be a preferred flowering time in the breeding program. Because of differences in flowering time, cross-pollination for hybrid production may require the storage of pollen for a certain period of time until receptive stigmas are available. This study showed that in glasshouse conditions $S$. formosa pollen may be left within the keel for a short period of no longer than 4 days before the viability is significantly reduced. However, in the breeding program, longer pollen longevity is usually needed. This requirement could be met by keeping the pollen grains in dry conditions at $4{ }^{\circ} \mathrm{C}$ and in total darkness. With this method pollen retained its viability for up to 28 days with a reasonably high germination rate. Pollen longevity was even greater with storage at $-10^{\circ} \mathrm{C}$ in total darkness. It is believed that $S$. formosa pollen might stand freezing conditions for more than 2 months.

The ability to tolerate desiccation and freezing suggests that low temperature storage may maintain pollen viability and longevity in $S$. formosa, which is beneficial in breeding programs. According to Gaff and Oliver (2013), desiccation-tolerant pollen contained less than $50 \%$ water when shedding. Franchi et al. (2011) claimed that pollen that were classified as desiccation-tolerant could usually survive low temperatures if they were first dried to a relatively low water content (one to five percent) without damage. In this study, the water content of $S$. formosa pollen at the time of storage initiation was $6.6 \%-7.3 \%$. 
Pollen preservation at low temperature has been tested in many plant species. Martinez-gomez et al. (2002) preserved pollen grains of almond at $0{ }^{\circ} \mathrm{C}$ and $4{ }^{\circ} \mathrm{C}$. It was found that at these two temperature regimes pollen longevity could reach 2 months with $80 \%$ pollen germination on BK medium. Prolonged storage for up to 12 months significantly reduced pollen germination to between 0 and $50 \%$, depending on cultivars. Giovannini et al. (2015) found that 'Encanto' rose pollen retained $92.2 \%$ germination after 192 days storage at $-20^{\circ} \mathrm{C}$. In Imperata cylindrica, Rather et al. (2017) also reported that better preservation of pollen was under $-20{ }^{\circ} \mathrm{C}$ that produced $46.97 \%$ absolute pollen viability after one month of preservation time. This pollen viability was significantly higher than of preservation regime of $4{ }^{\circ} \mathrm{C}(37.74 \%)$. Similarly, Mesnoua et al. (2018) reported that, at room temperature most date palm pollen lost their viability after two to three months of storage. However, under low temperature $\left(-20{ }^{\circ} \mathrm{C}\right.$ preferable $\left.4{ }^{\circ} \mathrm{C}\right)$ pollen viability can be extended for more than one year.

The resistance of $S$. formosa pollen to low storage temperatures could be due to the properties of its wall. Two layers, i.e. the outer and the inner layer, were found in the pollen wall of $S$. formosa (Figure 5A). Moore and Webb (1978) suggested that the outer layer of the pollen wall, which is called the exine, is made up of a protective substance known as sporopollenin, and the inner layer, which is called intine, is made up of cellulose and pectin. (Raven et al., 1999) added that sporopollenin is present in the pollen wall of all plants and is the most resistant biopolymer known. It is clear that the highly protective sporopollenin present at the outer layer, coupled with cellulose and pectin at the inner layer, contributes to the ability of $S$. formosa pollen grains to be resistant to low temperature, thus retaining their longevity.

Unlike pollen stored at $4{ }^{\circ} \mathrm{C}$, those pollen grains kept at $-10{ }^{\circ} \mathrm{C}$ were able to maintain their viability above $50 \%$ for the duration of the experiment (i.e. 63 days). Formation of intracellular ice crystals is believed to contribute to the extended longevity of $S$. formosa pollen at $-10{ }^{\circ} \mathrm{C}$. At the time of preservation, the water content of the $S$. formosa pollen was $6.6-7.3 \%$, which was sufficient for intracellular ice crystals to build up. This also occurred in Typha latifolia pollen with $7 \%$ water content, and stored at $-20{ }^{\circ} \mathrm{C}$ (Buitink et al., 1998). In Actinidia deliciosa, Gianni and Vania (2018) reported that pollen can be stored at $-18{ }^{\circ} \mathrm{C}$ up to three years, when pre-dried to 10 to $12 \%$. The increased longevity of dry pollen due to the presence of intracellular ice crystals is caused by slow molecular diffusion and decreased chemical reactions (Burke, 1996). Therefore, drying or cooling pollen grains into a glassy state might improve long-term storage of $S$. formosa pollen.

The presence of intracellular ice crystals may also cause abrasion of the exine wall of pollen, resulting in a greater uptake of water and nutrient by the intine during germination. The rate of pollen germination in $S$. formosa increased after several days of preservation at $-10{ }^{\circ} \mathrm{C}$, however, as the pollen underwent aging its viability slowly decreased. Further investigations, perhaps using scanning electron microscopy, on the preserved pollen grains would possibly provide more clues about the effect of low temperature leading to an insight on pollen longevity. This experiment showed that some non-germinating pollen grains were also found to be viable upon testing with acetoorcein. Perhaps these pollen grains would have germinated if the time of incubation of pollen grains on the germination medium increased beyond 120 minutes.

\section{Stigma receptivity}

Stigma receptivity is critical in the development of a flower to maturation. It may greatly influence the rate of self-pollination, pollination success at different stages in the flower life cycle, the importance of various pollinators, the interference between male and female functions, the rate of competition via improper pollen transfer, and the chances of gametophytic selection (Galen et al., 1987). Therefore, a test on the timing and duration of stigma receptivity should accompany breeding experiments or artificial pollination procedures (Stone et al., 1995). Receptivity may be influenced by some factors such as the age of the flower and the presence or absence of stigmatic exudate. Generally, the duration of stigma receptivity in most plant species varies from a few hours up to 10 days (Dafni, 1992).

Stigma receptivity has been studied in a number of ornamental plants such as Melaleuca alternifolia (Baskorowati, 2009), Mesosetum chaseae (Silva et al., 2013), Aechmea sp., Ananas sp., Alcantarea nahoumii, Pseudananas sagenarius and Vriesea sp. (Souza et al., 2016) and Lilium sp. (He et al., 2017). The receptivity can be determined based on its morphological changes, rate of pollen germination upon pollination, and enzymatic activity evaluation using staining method. However, Shivanna (2003) suggested that the best way to determine stigma receptivity is through artificial pollination followed by subsequent analysis of pollen germination until fruits and seeds are set.

The fairly high percentage of pod formation $(57.72 \%)$ resulted from plants emasculated one day before anther dehiscence indicated that the stigma had already been receptive before pollen maturity. At his stage, the petals were still closed but easily opened manually. This is in accordance with the finding of Jusaitis (1994) that the most convenient time for emasculating and performing hand-pollination on $S$. formosa was when the petals were still closed but easily opened using the fingers. This stage of floral development was approximately one day before anther dehiscence. Therefore, the earliest time for practically emasculating the flowers and carrying out handpollination in the present trial was one day before anther dehiscence. If emasculation is carried out earlier, it will damage the floral parts, particularly petals, because the flowers are still tightly closed and hard to open.

The receptivity of the stigma of $S$. formosa lasted up to the $6^{\text {th }}$ day after anther dehiscence, as indicated by a reasonably high percentage of pod formation $(60.43 \%)$. Pod formation significantly reduced on the next day, and no pods were produced through the pollination of stigma on the $9^{\text {th }}$ day after anther dehiscence as the stigma had 
completely lost its receptivity due to the initiation of floral abscission.

Receptive stigmas are characterised by high enzymatic activity. The presence of several enzymes such as dehydrogenases, esterases and peroxidases is found to coincide with this developmental stage (Shivanna and Rangaswamy, 1992). The stigma contains receptive cells that recognise the pollen grain and provides the substrate for pollen germination (Dafni, 1992). It also plays an important role in the selection of pollen, rejecting pollen of alien species as well as fungal spores (heslop-harrison, 1999). The stigmatic cells may have the capability to discriminate between self and non-self pollen, and specifically reject self pollen, thus preventing self-fertilization (Rea and Nasrallah, 2008).

The receptive stigmas of $S$. formosa are soft when rubbed with the fingertips because of the presence of liquid exudate. This wet stigma is a characteristic of the Fabaceae (Dafni, 1992). The exudate of the stigmas is important in pollen-pistil interaction, particularly in controlling pollen adhesion, hydration and germination, as well as providing nutrition to the pollen grain during its growth.

One important stigmatic feature in relation to the success of fertilisation is the osmotic pressure (OP) of stigmatic papillae. In self-incompatible plants such as Linum grandiflorum, the ratio of pollen OP to stigma OP was different (Murray, 1986). The difference in OP may be the reason for the failure of the pollen to hydrate, or may cause the pollen tube to burst, resulting in the failure of fertilisation even though the stigma is receptive. Since $S$. formosa is self-compatible the OP of stigma should not be a problem in interacting with the OP of viable pollen grains.

Another important element is the morphological structure of the stigma. Heslop-harrison (1999) suggested that the stigmatic surface of angiosperms shows a wide range of variation. It was reported by Jusaitis (1994) that the stigma of $S$. formosa is covered by a stigmatic cuticle that prevents pollen germination until ruptured. Such rupture can be induced by increasing fluid pressure in the style (Lord and Heslop-harrison, 1984) or subjecting the cuticle to mechanical disturbance such as visiting by birds (Heenan, 1998), bees (Sigrist and Sazima, 2004) or rubbing the stigma with fingertip (Zulkarnain, 2005), resulting in the rupturing of the cuticle. Although it may not directly correlate to stigma receptivity, misleading predictions of stigma receptivity in $S$. formosa may occur due to the presence of this cuticle.

\section{Conclusions}

The results indicate that hand-pollination in S. formosa could be performed at one day before anther dehiscence, but should be undertaken optimally 1-5 days after anther dehiscence, at which time the stigma is most receptive. When there are no receptive stigmas readily available for pollination, the pollen grains may be left within the keel in the glasshouse for a period of no more than 4 days. Alternatively, the pollen grains could be stored at a low temperature $\left(4^{\circ} \mathrm{C}\right)$ in total darkness, under which conditions pollen viability could remain high for up to 28 days. A longer period of pollen storage could be achieved by the use of freezing methodology $\left(-10^{\circ} \mathrm{C}\right)$, which allows storage of pollen for up to 63 days without any significant reduction in viability. Use of low temperature methodology should allow storage of $S$. formosa pollen for at least a few years, as noted in other species.

\section{Author Contribution}

Z.Z. ${ }^{0000-0002-7041-3535}$ : glasshouse and laboratory works, data collection and analysis, manuscript preparation and review. E.E. ${ }^{0000-0002-5525-1136}$ : data analysis and interpretation, manuscript preparation and review. E.I.S. ${ }^{0000-0002-2287-1849}$ : data analysis and interpretation, manuscript review.

\section{Acknowledgement}

The authors would like to thank Professor Acram Taji, Mick Faint and Garry Cluley from University of New England, Australia, for their supports in supplying and taking care of experimental plants in glasshouse, and helping in laboratory works.

\section{References}

ARATHI, H.S.; SACH, A.; COX, C.; KELLY, J.K. Autogamy and floral longevity in Mimulus guttatus. International Journal of Plant Science, v.163, n.4, p.567573, 2002. DOI: $10.1086 / 340444$

AVCI, S.; SANCAK, C.; CAN, A.; ACAR, A.; PINAR, N.M. Pollen morphology of the genus Onobrychis (Fabaceae) in Turkey. Turkish Journal of Botany, v.37, p.669-681, 2013. DOI: 10.3906/bot-1207-52

BANKS, H.; LEWIS, G. Phylogenetically informative pollen structures of 'caesalpinioid' pollen (Caesalpinioideae, Cercidoideae, Detarioideae, Dialioideae and Duparquetioideae: Fabaceae). Botanical Journal of the Linnean Society, v.187, n.1, p.59-86, 2018. DOI: 10.1093/botlinnean/boy005

BASKOROWATI, L. Stigma receptivity and pollen viability of Melaleuca alternifolia. Indonesian Journal of Forestry Research, v.6, n.1, p.26-36, 2009. DOI: 10.20886/ijfr.2009.6.1.26-37

BREWBAKER, J.L.; KWACK, B.H. The essential role of calcium ion in pollen germination and pollen tube growth. American Journal of Botany, v.50, p.859-865, 1963. DOI: 10.1002/j.1537-2197.1963.tb06564.x 
BUITINK, J.; WALTERS, C.; HOEKSTRA, F.A.; CRANE, J. Storage behaviour of Typha latifolia pollen at low water contents: interpretation on the basis of water activity and glass concepts. Physiologia Plantarum, v.103, p.145-153, 1998. DOI: 10.1034/j.1399-3054.1998.1030201.x

BURKE, M.J. The glassy state and survival of anhydrous biological systems. In: LEOPOLD, A.C. (ed.) Membranes, metabolism and dry organism. Ithaca NY: Cornell University Press, 1996. p.358-363.

COSTA, M.F.B.; PAULINO, J.V.; MARINHO, C.; LEITE, V.G.; PEDERSOLI, G.D.; TEIXEIRA, S. Stigma diversity in tropical legumes with considerations on stigma classification. The Botanical Review, v.80, n.1, p.1-29, 2014. DOI: $10.1007 / \mathrm{s} 12229-014-9131-5$

DAFNI, A. Pollination ecology - a practical approach. Oxford: Oxford University Press, Inc, 1992. 250p.

DONGARWAR, N.; THAKUR, U. Artificial pollination and its role in orchid conservation. In: MAKDE, K.H.; PAWAR, S.E. (eds.) A Glimpse of current vistas in Plant Science Research. Nagpur, India: Hislop College Publication Cell, 2014. p.123-140.

EDLUND, A.F.; SWANSON, R.; PREUSS, D. Pollen and stigma structure and function: The role of diversity in pollination. The Plant Cell, v.16, p.S84-S97, 2004. DOI: 10.1105/tpc.015800

FRANCHI, G.G.; PIOTTO, B.; NEPI, M.; BASKIN, C.C.; BASKIN, J.M.; PACINI, E. Pollen and seed desiccation tolerance in relation to degree of developmental arrest, dispersal, and survival. Journal of Experimental Botany, v.62, n.15, p.5267-5281, 2011. DOI:10.1093/jxb/err154

GAFF, D.F.; OLIVER, M. The evolution of desiccation tolerance in angiosperm plants: a rare yet common phenomenon. Functional Plant Biology, v.40, p.315-328, 2013. DOI: $10.1071 / \mathrm{FP} 12321$

GALEN, C.; ZIMMER, K.A.; NEWPORT, M.E. Pollination and floral scent morphs of Polemonium viscosum: a mechanism for disruptive selection on flower size. Evolution, v.41, n.3, p.599-606, 1987. DOI: 10.1111/ j.1558-5646.1987.tb05830.x

GIANNI, T.; VANIA, M. Artificial Pollination in Kiwifruit and Olive Trees. In: MOKWALA, P.W. (ed.), Pollination in Plants. London: IntechOpen Limited, 2018. p.59-80. DOI: 10.5772/intechopen.74831

GIOVANNINI,A.; MACOVEI,A.; CASER, M.; MANSUINO, A.; GHIONE, G.G.; SAVONA, M.; CARBONERA, D.; SCARIOT, V.; BALESTRAZZI, A. Pollen grain preservation and fertility in valuable commercial rose cultivars. Plants (Basel), v.6, n.2, p.1-8, 2017. DOI:10.3390/plants6020017
GIOVANNINI, A.; MACOVEI, A.; DONÀ, M.; VALASSI, A.; CASER, M.; MANSUINO, A.; GHIONE, G.G.; CARBONERA, D.; SCARIOT, V.; BALESTRAZZI, A.. Pollen grain preservation at low temperatures in valuable commercial rose cultivars. Acta Horticulturae, v.1064, p.63-66, 2015. DOI: 10.17660/ActaHortic.2015.1064.7

GUPTA, A.; GODARA, R.K.; SHARMA, V.K.; PANDA, A.K. Artificial pollination: a tool for improving fruiting traits in date palm (Phoenix dactylifera L.). Chemical Science Review and Letters, v.6, p.1312-1320, 2017.

HE, G.; HU, F.; MING, J.; LIU, C.; YUAN, S. Pollen viability and stigma receptivity in Lilium during anthesis. Euphytica, v.213, n.10, p.231-240, 2017. DOI: 10.1007/ s10681-017-2019-9

HEENAN, P.B. The pollination system and stigmatic cuticle of Clianthus puniceus (Fabaceae). New Zealand Journal of Botany, v.36, p.311-314, 1998. DOI: 10.1080/0028825X.1998.9512571

HESLOP-HARRISON, J.S. Aspects of the cell biology of pollination and wide hybridisation. In: CRESTI, M.; CAI, G.; MOSCATELLI, A. (eds.) Fertilisation in higher plants: molecular and cytological aspects. Berlin, Heidelberg: Springer-Verlag, 1999. p.140-144.

HUGHES, H.G.; LEE, C.W.; TOWILL, L.E. Lowtemperature preservation of Clianthus formosus pollen. HortScience, v.26, p.1411-1412, 1991. DOI: 10.21273/ hortsci.26.11.1411

IKEDA, H.; NUMATA, S. Pollen storage of chrysanthemum. Acta Horticulturae, v.454, p.329-333, 1996. DOI: 10.17660/ActaHortic.1998.454.38

JUSAITIS, M. Floral development and breeding system of Swainsona formosa (Leguminosae). HortScience, v.29, n.2 p.117-119, 1994. DOI: 10.21273/HORTSCI.29.2.117

LORD, E.M.; HESLOP-HARRISON, Y. Pollen-stigma interaction in the Leguminosae: stigma organisation in the breeding system in Vicia faba L. Annals of Botany, v.54, n.6 p.827-836, 1984. DOI: 10.1093/oxfordjournals.aob. a086856

MACHADO, C.D.A.; MOURA, C.R.F.; LEMOS, E.E.P.D.; RAMOS, S.R.R.; RIBEIRO, F.E.; LÉDO, A.D.S. Pollen grain viability of coconut accessions at low temperatures. Acta Scientiarum, v.36, n.2, p.227-232, 2014. DOI: 10.4025/actasciagron.v36i2.17346

MANGENA, P.; MOKWALA, P.W. Introductory chapter: pollination. In: MOKWALA, P.W. (ed.) Pollination in plants. London: IntechOpen Limited, 2018. p.1-6. DOI: 10.5772/intechopen. 77227 . 
MARTINEZ-GOMEZ, P.; GRADZIEL, T.M.; ORTEGA, E.; DICENTA, F. Short-term storage of almond pollen. HortScience, v.35, n.6 p.1151-1152, 2000. DOI: 10.21273/ HORTSCI.35.6.1151

MARTINEZ-GOMEZ, P.; GRADZIEL, T.M.; ORTEGA, E.; DICENTA, F. Low temperature storage of almond pollen. HortScience, v.37, n.4, p.691-692, 2002. DOI: 10.21273/HORTSCI.37.4.691

MESNOUA, M.; ROUMANI, M.; SALEM, A. The effect of pollen storage temperatures on pollen viability, fruit set and fruit quality of six date palm cultivars. Scientia Horticulturae, v.236, p.279-283, 2018. DOI: 10.1016/j. scienta.2018.03.053

MOORE, P.D.; WEBB, J.A. An Illustrated Guide to Pollen Analysis. London: Hodder and Stoughton, 1978. $133 p$.

MURRAY, B.G. Floral biology and self-Incompatibility in Linum. Botanical Gazette, v.147, n.3, p.327-333, 1986. DOI: $10.1086 / 337599$

PARTON, E.; VERVAEKE, I.; DELEN, R.; VANDENBUSSCHE, B.; DEROOSE, R.; PROFT, M.D. Viability and storage of bromeliad pollen. Euphytica, v.125, n.2, p.155-161, 2002. DOI: 10.1023/A:1015884019619

PRAKASH, N. Methods in plant microtechnique. Armidale, Australia: University of New England, 2000. $63 \mathrm{p}$.

RATHER, S.A.; CHAUDHARY, H.K.; KAILA, V. Pollen preservation potential of Imperata cylindrica - an efficient source for doubled haploid production in wheat. Cereal Research Communications, v.45, n.3, p.525-534, 2017. DOI: $10.1556 / 0806.45 .2017 .026$

RAVEN, P.H.; EVERT, R.F.; EICHHORN, S.E. Biology of plants. New York: W.H. Freeman and Company, 1999. 900 p.

REA, A.C.; NASRALLAH, J. B. Self-incompatibility systems: barriers to self-fertilization in flowering plants. International Journal of Developmental Biology, v.52, p.627-636, 2008. DOI: 10.1387/ijdb.072537ar

SHIVANNA, K.R. Pollen Biology and Biotechnology. Boca Raton: CRC Press, 2003. 316p.

SHIVANNA, K.R.; OWENS, S.J. Pollen-pistil interactions (Papilionoideae). In: STIRTON, C.H.; ZARUCCHI, J.L. (eds.) Advances in Legume Biology: monograph of systematic botany. Missouri, USA: Missouri Botanical Garden, 1989. p.157-182.
SHIVANNA, K.R.; RANGASWAMY, N.S. Pollen Biology: a laboratory manual. Berlin: Springer-Verlag, 1992. 119p.

SIGRIST, M.R.; SAZIMA, M. Pollination and reproductive biology of twelve species of neotropical Malpighiaceae: Stigma morphology and its implications for the breeding system. Annals of Botany, v.94, p.33-41, 2004. DOI: 10.1093/aob/mch108

SILVA, L.A.C.; PAGLIARINI, M.S.; SANTOS, S.A.; VALLE, C.B. Stigma receptivity, mode of reproduction, and mating system in Mesosetum chaseae Luces (Poaceae), a native grass of the Brazilian Pantanal. Genetics and Molecular Research, v.12, n.4, p.5038-5045, 2013. DOI: 10.4238/2013.October. 25.2

SOUZA, E.H.; CARMELLO-GUERREIRO, S.M.; SOUZA, F.V.D.; ROSSI, M.L.; MARTINELLI, A.P. Stigma structure and receptivity in Bromeliaceae. Scientia Horticulturae, v.203, p.118-125, 2016. DOI: 10.1016/j. scienta.2016.03.022

STONE, J.L., THOMPSON, J.D.; DENT-ACOSTA, S.J. Assessment of pollen viability in hand-pollination experiments: a review. American Journal of Botany, v.82, n.9, p.1186-1197, 1995. DOI: 10.1002/j.1537-2197.1995. tb11591.x

TAPINGKAE, T.; TAJI, A.; KRISTIANSEN, P. Flowering of Sturt's desert pea (Swainsona formosa) is affected by changes in glucose concentration in shoot apices. Acta Horticulturae, v.813, p.599-603, 2009. DOI: |10.17660/ ActaHortic.2009.813.83

VITHanage, V. Pollination technique in pistachio breeding. In: WILLIAMS, E.G.; KNOX, R.B. (eds.) Pollination '84. Melbourne, Australia: The School of Botany University of Melbourne, 1984. p.167-175.

ZULKARNAIN, Z. Embryology of Swainsona formosa (Fabaceae): Anther and ovule development. Hayati: Journal of Biosciences, v.12, n.1, p.11-16, 2005. DOI: 10.1016/S1978-3019(16)30317-5

ZULKARNAIN, Z. The detection of the time of conversion from vegetative to reproductive growth in Swainsona formosa (Fabaceae). Agroecotania, v.1, n.1, p.1-10, 2018. DOI: 10.22437 /agroecotania.v1i1.5312 